\title{
Assessment of Undiscovered Continuous Oil and Gas Resources in the Monterey Formation, San Joaquin Basin Province, California, 2015
}

\begin{abstract}
Using a geology-based assessment methodology, the U.S. Geological Survey assessed mean volumes of 21 million barrels of oil (MMBO), 27 billion cubic feet of gas, and 1 million barrels of natural gas liquids in two assessment units (AUs) that may contain continuous oil resources. Mean volumes of oil for the individual assessment units are $14 \mathrm{MMBO}$ in the Monterey Buttonwillow AU and $7 \mathrm{MMBO}$ in the Monterey Maricopa AU.
\end{abstract}

\section{Introduction}

The U.S. Geological Survey (USGS) recently completed a geology-based assessment of technically recoverable continuous oil and gas resources in the Miocene Monterey Formation in the southern San Joaquin Basin of central California (fig. 1). The Monterey Formation is the source rock for most of the oil in structural and stratigraphic traps in the San Joaquin Basin, including several fields with multiple billions of barrels of recoverable oil. Recent drilling programs targeting oil remaining in the source rock, however, appear unsuccessful to date.

Gautier and others (2007) estimated the potential for undiscovered, conventionally trapped petroleum accumulations, and Tennyson and others (2012) estimated potential additions to reserves in discovered accumulations (including Monterey Formation reservoirs in conventionally trapped accumulations, such as Elk Hills and Lost Hills). The present assessment encompasses Monterey rocks that may contain a continuous accumulation in or near the zone of petroleum generation, where in-situ petroleum that has not migrated to shallower conventional traps could still be present. Two assessment units (AUs) were defined for these rocks: (1) the Monterey Buttonwillow Continuous Oil AU and (2) the Monterey Maricopa Continuous Oil

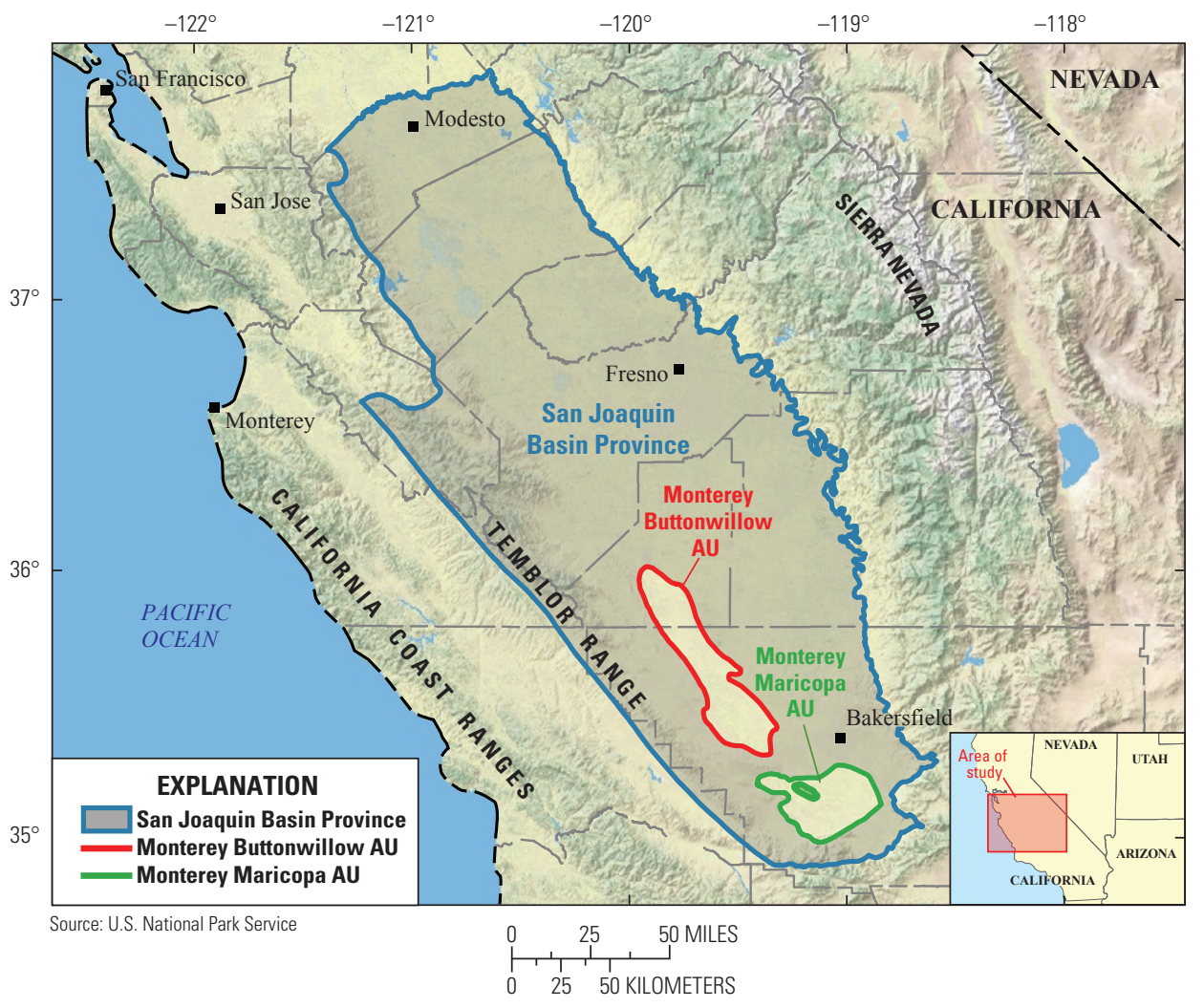

Figure 1. Map of the San Joaquin Basin Province. Assessment unit (AU) boundaries approximate the 10,000-foot structure contour on the top of the Monterey Formation, as revised from maps of Webb (1981) and Graham and Williams (1985) using well penetrations from data available online from the California Division of Oil, Gas, and Geothermal Resources.

AU. Conventionally trapped oil and gas fields with oil-water contacts were excluded from the areas of the AUs.

\section{Geologic Summary}

Strata in the San Joaquin Basin record 120 million years of forearc deposition along a convergent continental margin, which was succeeded about 20 million years ago by a transition to transform motion along the San Andreas Fault system. The middle to upper Miocene Monterey Formation was deposited after this transition, from about 17 to 5 million years ago, while the coastline was well landward of its present position and relatively little coarse terrigenous sediment was transported offshore. The Monterey Formation comprises fine-grained, organic-rich strata with a substantial biogenic component, mainly diatoms and foraminifera, as well as interbedded deep marine sandstone in the southernmost part of the basin. Typically about 2,000 feet (ft) thick, it ranges up to about twice that thickness in the deepest parts of the basin. A structural high near Bakersfield separates the San Joaquin Basin into the Buttonwillow depocenter to the north and the Maricopa depocenter to the south. The top of the Monterey Formation reaches depths of over $14,000 \mathrm{ft}$ in the Buttonwillow depocenter and 15,000 ft 
in the southernmost part of the Maricopa depocenter. Generation of oil began as the Monterey reached burial depths of about $12,000 \mathrm{ft}$ within the last few million years. Assessment unit boundaries outline the areas where at least part of the Monterey is buried deeply enough to generate oil. Most oil readily migrates upward along natural fractures, faults, and interbedded sandstones to structural and stratigraphic traps. More than 80 wells have penetrated the Monterey Formation where it is deep enough to have generated oil, but none has returned more than small volumes of oil outside conventional traps.
Table 1. Key assessment input data for the two continuous assessment units in the San Joaquin Basin Province, California.

[EUR (estimated ultimate recovery per well); MMBO, million barrels of oil; $\mathrm{AU}$, assessment unit; \%, percent. The average EUR input is the minimum, median, maximum, and calculated mean]

\begin{tabular}{|l|c|c|c|c|}
\hline \multicolumn{7}{|c|}{ Assessment input data-continuous AUs } \\
\hline \multicolumn{1}{|c|}{ Monterey Buttonwillow AU } & Minimum & Mode & Maximum & Calculated mean \\
\hline Potential production area of AU (acres) & 5,000 & 182,000 & 343,000 & 176,667 \\
\hline Average drainage area of wells (acres) & 5 & 10 & 40 & 18 \\
\hline Success ratio (\%) & 5 & 10 & 50 & 21.7 \\
\hline Average EUR (MMBO) & 0.003 & 0.005 & 0.02 & 0.006 \\
\hline AU probability & 1.0 & \multicolumn{4}{|c|}{} \\
\hline \multicolumn{1}{|c|}{ Monterey Maricopa AU } & Minimum & Mode & Maximum Calculated mean \\
\hline Potential production area of AU (acres) & 5,000 & 113,000 & 223,000 & 113,667 \\
\hline Average drainage area of wells (acres) & 5 & 10 & 40 & 18 \\
\hline Success ratio (\%) & 5 & 8 & 40 & 17.7 \\
\hline Average EUR (MMBO) & 0.003 & 0.005 & 0.02 & 0.006 \\
\hline AU probability & 1.0 & \multicolumn{3}{l}{} \\
\hline
\end{tabular}

Table 2. Assessment results for continuous oil and gas resources in the San Joaquin Basin Province, California.

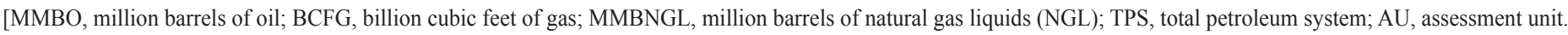

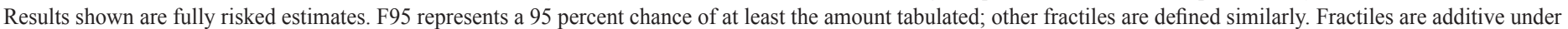
assumption of perfect positive correlation]

\begin{tabular}{|c|c|c|c|c|c|c|c|c|c|c|c|c|c|c|}
\hline \multirow{3}{*}{$\begin{array}{l}\text { Total Petroleum System (TPS) } \\
\text { and } \\
\text { Assessment Units (AU) }\end{array}$} & \multirow{3}{*}{$\begin{array}{l}\text { AU } \\
\text { prob- } \\
\text { ability }\end{array}$} & \multirow{3}{*}{$\begin{array}{l}\text { Accu- } \\
\text { mulation } \\
\text { type }\end{array}$} & \multicolumn{12}{|c|}{ Total undiscovered resources } \\
\hline & & & \multicolumn{4}{|c|}{ Oil (MMBO) } & \multicolumn{4}{|c|}{ Gas (BCFG) } & \multicolumn{4}{|c|}{ NGL (MMBNGL) } \\
\hline & & & F95 & F50 & F5 & Mean & F95 & F50 & F5 & Mean & F95 & F50 & F5 & Mean \\
\hline \multicolumn{15}{|c|}{ Miocene TPS } \\
\hline Monterey Buttonwillow AU & 1.0 & Oil & 2 & 10 & 35 & 14 & 3 & 14 & 47 & 18 & 0 & 1 & 2 & 1 \\
\hline Monterey Maricopa AU & 1.0 & Oil & 1 & 5 & 18 & 7 & 2 & 7 & 25 & 9 & 0 & 0 & 1 & 0 \\
\hline Total unconventional resources & & & 3 & 15 & 53 & 21 & 5 & 21 & 72 & 27 & 0 & 1 & 3 & 1 \\
\hline Total undiscovered resources & & & 3 & 15 & 53 & 21 & 5 & 21 & 72 & 27 & 0 & 1 & 3 & 1 \\
\hline
\end{tabular}

This USGS analysis, based on drilling results to date, concluded that some recoverable oil probably remains in the source rock, but success rates (proportion of drilled wells that produce at least 2,000 barrels) will be low, and the estimated ultimate recovery will be low for even successful wells (table 1). Wells will be relatively tightly spaced, as they are in producing Monterey reservoirs in conventional traps such as those at the Buena Vista and Lost Hills fields. Anticipated extraction methods are mostly vertical (rather than horizontal) wells, acid stimulation, and hydraulic fracturing.

\section{Resource Summary}

The USGS assessed undiscovered, technically recoverable continuous (unconventional) oil and gas resources in two AUs in the Monterey Formation of the San Joaquin Basin Province (table 2). Assessed means are $14 \mathrm{MMBO}, 18$ billion cubic feet of gas (BCFG), and 1 million barrels of natural gas liquids (MMBNGL) in the Monterey Buttonwillow AU and $7 \mathrm{MMBO}, 9 \mathrm{BCFG}$, and $0 \mathrm{MMBNGL}$ in the Monterey Maricopa AU.

\section{References Cited}

Gautier, D.L., Hosford Scheirer, Allegra, Tennyson, M.E., Peters, K.E., Magoon, L.B., Lillis, P.G., Charpentier, R.R., Cook, T.A., French, C.D., Klett, T.R., Pollastro, R.M., and Schenk, C.J., 2007, Executive summary-Assessment of undiscovered oil and gas resources of the San Joaquin Basin Province of California, 2003, chap. 1 of Hosford Scheirer, Allegra, ed., Petroleum systems and geologic assessment of oil and gas in the San Joaquin Basin Province, California: U.S. Geological Survey Professional Paper 1713. [Available at http://pubs.usgs.gov/pp/pp1713/01/pp1713_ch01.pdf.]

Graham, S.A., and Williams, L.A, 1985, Tectonic, depositional, and diagenetic history of Monterey Formation (Miocene), central San Joaquin Basin, California: American Association of Petroleum Geologists Bulletin, v. 69, no. 3, p. 385-411.

Tennyson, M.E., Cook, T.A., Charpentier, R.R., Gautier, D.L., Klett, T.R, Verma, M.K., Ryder, R.K., Attanasi, E.D., Freeman, P.A., and Le, P.A., 2012, Assessment of remaining recoverable oil in selected major oil fields of the San Joaquin Basin, California: U.S. Geological Survey Fact Sheet 2012-3050, 2 p., accessed June 2013 at http://pubs.usgs.gov/fs/2012/3050/.

Webb, G.W., 1981, Stevens and earlier Miocene turbidite sandstones, southern San Joaquin Valley, California: American Association of Petroleum Geologists Bulletin, v. 65, no. 3, p. 438-465.

\section{For Further Information:}

Assessment results are available at the USGS Central Energy Resources Science Center Web site: http://energy.usgs.gov/OilGas/AssessmentsData/ NationalOilGasAssessment/Publications.aspx.

\section{San Joaquin Monterey Assessment Team}

Marilyn E. Tennyson, Ronald R. Charpentier, Timothy R. Klett, Michael E. Brownfield, Janet K. Pitman, Stephanie B. Gaswirth, Sarah J. Hawkins, Paul G. Lillis, Kristen R. Marra, Tracey J. Mercier, Heidi M. Leathers, Christopher J. Schenk, and Katherine J. Whidden 